\title{
CODE MIXING USED BY STUDENTS OF FRENCH STUDY PROGRAM STATE UNIVERSITY OF MEDAN
}

\author{
Windi Sahputra Barus, Mhd. Pujiono, Hesti Fibriasari \\ Faculty of Social Sciences \\ University of Sumatera Utara \\ E-mail: windi_sahputra_barus@yahoo.co.id
}

Received: 21 January 2019

Accepted: 15 April 2019

\begin{abstract}
The communication process involving a code mixing is an alternative to avoid misunderstandings in a bilingual community, a community having the phenomenon of speaking and understanding two or more languages, referring either to individuals or the entire society. This study aims to analyze the forms of code mixing using qualitative method. The data were obtained from recording of conversational discourse. The data collection strategy used the referral method, supported by basic techniques, namely tapping and advanced techniques, the skillful in-flight listening technique (SBLC). The results show that there are code mixing with the insertion of morphological elements in forms of nouns, numerals, verbs (infinitive and conjugation), adverbs (question and time), and adjectives; the insertion of phrase in terms of noun phrases (objects and numerals), verb phrases, and adverb phrases); the insertion of clause in the forms of noun clauses, numeral clauses, verb clauses, and adverb clauses; and the insertion of idiomatic forms. Code mixing of students of French language is also found in English language.
\end{abstract}

Keywords: sociolinguistics, bilingualism, code mixing

\section{Introduction}

The social life of a community cannot be separated from language interaction. Keraf (2009: 2) states that there are two meanings of language. The first definition states that language is categorized as a means of communication between members of the community in the form of sound symbols produced by human utterances. The second definition, language is a communication system that uses arbitrary symbols (speech sounds). Basically, language has functions as a tool for communicating, as a tool for carrying out social integration and adaptation in certain environments or situations, and as a tool for carrying out social control. But from the sociolinguistic point of view the concept that language is a tool or function to convey thoughts is considered too narrow because Fishman previously mentions that what becomes a sociolinguistic problem is "Who speak the language, to whom, when and to what end". Therefore, the functions of the language, among others, can be seen from the speaker, listener, topic, code and message mandate. Furthermore, Chaer and Agustina (2010: 14) reveal that language functions as a tool to interact or a tool to communicate, in the sense that the tool is to convey thoughts, ideas, concepts, and also feelings. So the role of language in people's lives is very important and irreplaceable. Therefore, people are required to use language wisely so that the message they want to convey can be easily accepted by others. 
It must be known that a language has a system and subsystem understood by fellow speakers of the language. However, though speakers of the language are in a speech society, they are not included in a homogeneous group of humans, so concrete forms of language become varied. The occurrence of diversity or variance of language is not only caused by the speakers who are not homogeneous, but also the activities of social interaction (Chaer, 2004: 61). Bell (1976: 252) states that "There are no single style speakers of a language because each individual controls and uses a variety of linguistic styles and no one speaks in exactly the same way in all circumstances." That means there are no speakers who use the same language style. Thus, variations in language, such formal or informal; speech level, registers, and dialects, with various phenomena of language use are controlled by social and situational factors. This has an impact on the emergence of code mixing.

Sumarsono (2007: 202-203) states that "campur kode terjadi apabila penutur menyelipkan unsur-unsur bahasa lain ketika sedang memakai bahasa tertentu", meaning that code mixing happens when a speaker inserts other language elements when using a certain language. In other words, code mixing occurs when two elements of language are intentionally used side by side and completed each other. Note the following discourse fragments:

A: kita mau pigi kemana we?

B: shopping aja lah yok ke carefour.

gimana?

C:allez-y, suntuk juga ga da kegiatan.

A: oke, let's go guys.

In the fragment of discourse, the process of changing language or the variety of languages is caused by circumstances. It is also inseparable from the component of bilingualism (ability in two languages). Language styles of $A, B$ and $C$, are casual conversations between friends, and there are foreign languages inserted into Indonesian such as the words shopping, carefour, allez-y, oke let's go guys. These expressions have an impact on the use of words that are more appropriate for conveying messages or intentions. The communication is running well without ambiguity. The insertions of these elements into the structure of the Indonesian language are termed coded events with different forms.

The students of French Study Program at State University of Medan constitute one example of a bilingual community who know more than one language (Indonesian and French). As a result of learning a new language, or the second language in this study, that is French, many new language terms are inherent among students of French Study Program, especially in language activities; consequently, in the process of communication, students often use code mixing. Simple examples in this case are greetings among students of French Study Programs, accustomed to greeting fellow students or lecturers with the words "bonjour/bonsoir" and not with "good morning/good afternoon". And the term "Madame/Monsieur" is more often used than "Mam/Sir". Based on the background, this paper is carried out to identify and analyze the forms of the code mixing in the discourse of conversation performed by students of French Study Program, in the State University of Medan.

\section{Literature Review}

Sociolinguistics is a study of languages and their uses in public communication. As said by Fishman (1972: 4) that "Sociolinguistics is the study of the characteristics of language varieties, the characteristics of their functions, and the characteristics of their speakers as 
these three constantly interact, change and change one another within a speech community." It is said that, sociolinguistics is included in a study that discusses variations in language, functions of variations of the language, and the characters found in users of that language. Sociolinguistics is the basis of language research in society that is related to language interaction by showing the variety of languages that are often used in conversational situations between speakers and partners. Therefore, sociolinguistics discusses variations in language. Variation of language is the occurrence of diversity or variance of language. The process is seen from the interactions taking place within members of a community

Weinrich (1968: 1) states that bilingualism is the practice of alternately using two languages. In the use of two or more languages, the speakers are not required to master both languages with the same fluency. In other words, the first and the second languages do not have to be mastered fully. However, the use of the second language is only used to facilitate the interaction process in conversation.

Suwandi (2008: 87) states that code mixing is "penggunaan dua bahasa atau lebih atau ragam bahasa secara santai antara orang-orang yang kita kenal dengan akrab." In other words, code mixing is two elements of language that have interrelations in their use. Then, Kachru (1982: 39), divides the code mixing into five forms: 1) Unit Insertion, 2) Unit Hybridization, 3) Sentence Insertion, 4) Idiom and Collocation Insertion, and 5) Reduplication Insertion. The problems in this paper are analyzed by referring to this view.

The previous research used as a reference is "Code Switching in the French School: Examining a Multilingual Setting in Kuwait" by Algharabali, Alhaidari and Taqi 1 in 2015 . The conclusion in the mentioned paper is that code switching and code mixing process is beneficial for students in interacting mainly from Arabic into English, while French is considered learning medium, besides teachers and parents are also facilitators in helping students in code switching.

Another article is "Les phénomènes de code-switching dans les conversations adulteenfant(s) en basque-espagnol : une approche syntaxique" by Ezeizabarrena and Aeby in 2016. The results of this related research show that the forms of code switching and code mixing of children's speech are more dominant than those of the internal forms, specifically, the ability of bilingual children to separate the grammar system during the initial stages of acquisition. The contribution of the research is to quantitatively describe the ability of children to switch codes and mix codes so that they know the types of code mixing and the attitude of the language used.

\section{Research Method}

The method used in this paper is a qualitative method. The data sources of this research are students of French language study program at University of Medan, standing as informants to obtain qualitative data. By using the stratified proportional random sampling technique, students of the first, third, and fifth semester are selected, participating in the "Production Orale" course focusing on student speaking competencies. Data obtained from various events or speech scenes in the form of oral data (oral language) are transcribed in written form containing the interfering code events. Data are obtained by recording (audio / video) as well as images showing the field situation during the conversation interaction in the French Language Study Program, both in formal situations or in a relaxed atmosphere, such as in the teaching and learning process in the classroom and outside, in non-formal discussion activities. 
The data collection strategy used is the referral method, supported by basic techniques, namely tapping techniques, and advanced techniques, skillful in-flight listening techniques (SBLC) (Sudaryanto, 2015: 203-205).Conversational interactions that take place among students are observed carefully then followed by recording techniques, namely recording the discourse of the conversation. After that the data are analyzed with the following strategies (1) data reduction, namely the diversity of language code variations, language choice patterns, funding factors that determine language choices, (2) data presentation, (3) recording data records with descriptions of conversation situations, (4) grouping recorded data with records compiled during the recording process; and (5) concluding on the language choices in language events. The results of data analysis in the form of research findings are presented in an informal method. The informal method is intended to present the results of data analysis in the form of ordinary words in sociolinguistic terminology. After the data are collected, data processing is carried out into several stages. The first, is transcribing oral language into written language, so that the description of the occurrence of the code mixing is obtained, then from the data selected, speeches are analyzed. The final stage is classifying the forms of code mixing based on the code mixing in the conversation discourse of students of the French Study Program.

\section{Result and Discussion}

The forms of code mixing in conversation discourse of the students of French Study Program at State University of Medan refer to Kachru's (1982) theory:

\subsection{Unit Insertion}

Words are included in the smallest and independent unit of language and have meaning combining the code in conversation discourse; Unit Insertion identified is code mixing in the forms of nouns, verbs, and adverbs.

Table 1. Unit Insertion

\begin{tabular}{|l|l|l|}
\hline No. & \multicolumn{1}{|c|}{ Unit Insertion } & \multicolumn{1}{c|}{ The form of code mixing } \\
\hline 1. & Nouns (feminine) & Terkejut dia Madame \\
\hline 2. & Nouns (Masculine) & kira-kira itu problem \\
\hline 3. & Nouns (Plural) & maksudnya les vidéos kami ini Madame \\
\hline 4. & Numbers & deux tahun, \\
\hline 5. & Verbs (Infinitive) & biar dia se presenter \\
\hline 6. & Verbs (Conjunction) & attendez ya Madame \\
\hline 7. & Adverbs & nah, où ? / ya kan., makanya maintenant \\
\hline 8. & Adjectives & wuih enak Madame, intéressant \\
\hline
\end{tabular}

The word "madame" is included in the form of noun with female gender "feminine" and has the meaning of "Mam". The word "madame" is used by the students at the French Language Study Program referring to "Mam", a call for female lecturer. In the word "problème", the insertion of the said word elements is intended by the speaker to indicate the state of the word "problème" meaning to state "a problem" in Indonesian, The word "problème" includes the noun word of "masculine" gender. "Les videos", are included in the form of noun with plural status (more than one object). "Les vidéos" means "the videos". In addition, code mixing in other noun forms is a numeral that indicates the number of things. 
The "deux year" quotes means "two years. The insertion of French elements in the words of "se presenter" as verbs means "introducing oneself". In French, the word "se presenter" is included in the basic verb "le verbe infinitive" form because it has not undergone a change in the verb "conjugaison". As with "attendez", the insertion of the said word element is in the form of verb that has been conjugated with subject "vous". The other word forms identified are adverbs in the form of question words such as "comments" "how», "quand" "when", "qui" "who", and "oü" "where». The insertion of these adverbs is used by students to ask something when speaking. Beside the form of question words, insertion of adverb form is also found in the form of time descriptions as in the word "maintenant". The last word found is insertion in adjective as "intéressant".

In addition to the insertion of words in French, in the discourse of the student conversation, insertions of English words are also found.

a. Speechless Madame.

b. kau tau masukkan gambar dari photoshop

c. Dragaja.

d. mang kaya gitu, error dia pas dimasukkan

e. dengar audio, baru, sama buat pertanyaan,

Therefore, it is concluded that code mixing is found in the discourse of conversation of students, that is the insertion of French words and also English words into the structure of Indonesian language with nouns, verbs, adjectives and adverbs.

\subsection{Unit Hybridization}

Phrase is the combination of two or more words that are not predictive and can be a combination of one category with another. Unit Hybridization identified in phrases is code mixing in the forms of nouns, numbers, verbs, and adverbs.

Table 2. Unit Hybridization

\begin{tabular}{|l|l|l|}
\hline No. & Unit Hybridization & \multicolumn{1}{c|}{ The form of code mixing } \\
\hline 1. & Noun Phrases & son nom Muhammad Syafikra \\
\hline 2. & Number Phrases & klo ada dua saudara laki-laki sebenarnya deux frère \\
\hline 3. & Verb Phrases & oke Falen, allez-y \\
\hline 4. & Adverb Phrases & la classe de Seni \\
\hline
\end{tabular}

The insertion of the phrase the "son nom" has the meaning of "name". The phrase consists of the attributes belonging to the third person, "son" followed by "masculine" gender with the meaning of "his name". The insertion is included in the noun phrase. Another noun phrase is in numeral form as in the example of "deux frère". The structure of the word is formed by the number "deux" followed by the noun of the boy "frère". The phrase means "two brothers". The phrase "allez-y", is the insertion in the form of verb phrase. This is because the phrase is formed from the conjugated verb of the subject "vous" so that it changes from the basic "infinitive" verb that is aller to the form of conjugated verb "allez". The verb is followed by the "- $y$ " attribute which serves as a determinant of "pointer" to form a verb phrase that means "please go there / go there». The last form found in the conversation discourse is the insertion of an element in the form of an adverb phrase, as found in the sample data in the phrase of "la classe de" art. The structure of the phrase is 
Code Mixing of French Study Program Students at the State University of Medan, Windi Sahputra Barus, Mhd. Pujiono, Hesti Fibriasari

formed from the prepositions of "in» followed by the noun "la classe" meaning "class" and the preposition " $d e$ " as a marker for the word Art; the speaker conveys something that takes place in the art class.

In addition to insertion in the form of the French language, the insertion of English elements is also found in the form of phrases.

a. mana open with? oh ini...

a. aku nge-test sound-nya dulu sebentar.

b. photoshop sih Madame saya makenya, ngga 360

c. belum move on ya dari semester satu.

d. jadi mungkin kita flashback lagi

Therefore, it is concluded that code mixing is found in the discourse of conversation of students in the forms of the insertion of phrases from French, as well as English into the structure of the Indonesian language with noun phrases (objects and numerals), verb phrases, and adverb phrases.

\subsection{Sentence Insertion}

Clause is a combination of several words consisting of subject and predicate. The code mixing identified is in the forms of clauses: nouns, verbs, adverbs, and numerals.

Table 3. Sentence insertion

\begin{tabular}{|l|l|l|}
\hline No. & Sentence insertion & \multicolumn{1}{|c|}{ The form of code mixing } \\
\hline 1. & Noun Clauses & I/ a vingt-huit, dua puluh delapan \\
\hline 2. & Number clauses & $\begin{array}{l}\text { Madame jangan ketawa ya Madame, II } \\
\text { y a beaucoup de problèms }\end{array}$ \\
\hline 3. & Verb clauses & makanya on va regarder les vidéos \\
\hline 4. & Adverb clauses & mais, la dernier temps il écrit iya kan ? \\
\hline
\end{tabular}

In the clause "Il a vingt-huit", the type of code mixing is in the form of noun clauses. Based on the syntactic structure, the clause is formed from a combination of groups of words that are cored on the subject, namely the third person singular "il", then, followed by the conjugated verb " $a$ " "from the basic verb avoir" and the numeral phrase "vingt-huit" which means 28 . Overall the clause means "he is 28 years old". In addition to the noun clause, a numeral clause is also found, as in the example of "il y a beaucoup de problèms". The clause means "there are many problems", the clause is based on the numerical "beaucoup" so that the clause is a numeral clause. Another form of code mixing is the insertion of elements of French in the form of verb clauses. The verb clause is said because the position of the verb is the core of the clause as in the example of "on va regarder les vidéos". The clause structure is formed from a single third person subject "on" followed by conjugated " $v a$ " "verbs of aller in infinitive verbs" and infinitive verbs "regarder" then followed by plural nouns namely "les vidéos" "plural signs or more than one known from the current article usage (particle) for plural objects and at the end of a noun, the letter $-s$ is added as a determinant of nouns more than one ". The clause means "we will see the videos". The last clause form found in the conversation discourse is the adverb clause as in the data "mais, la dernier temps il écritiya kan?" Based on the structure in the clause, the time adverb becomes the core of the clause. The clause is formed from the "mais" 
conjunction followed by the adverb phrase "la dernier temps" which states in the last time, then followed by the object in the form of a single third-person noun "il" and the conjugated verb "écrit" from the ecrire basic verb. The adverb clause means "but, at the last time he wrote". The clause shows that at the last moment he (the actor) just starts writing.

In addition to the insertion of French language clauses, the insertion of foreign language elements into the structure of the Indonesian language in the discourse of the students of French Language Study Program conversations at UNIMED also occurs in the form of English clauses, as in the data "try to give me some ideas ..." but such a clause is rarely found.

\subsection{Idiom Insertion}

In addition to the three forms of insertion above (words, phrases, and clauses), the insertion of French idioms is also found. Idioms are expressions, which are formed from words or phrases with random structures, so that the expression has meaning outside the text.

Table 4. idiom insertion

\begin{tabular}{|l|l|l|}
\hline No. & \multicolumn{1}{|c|}{ idiom insertion } & \multicolumn{1}{c|}{ The form of code mixing } \\
\hline 1. & Idiom & oh la la! Nantikan bisa loh... \\
\hline 2. & Idiom & kayak déjà vu gitu kurasalah... \\
\hline
\end{tabular}

The phrase "oh la la!" is an idiom that has no meaning in structure. But if viewed from the semantic side, the expression has a meaning in the form of someone's expression of displeasure or dislike of something. In addition, in the example of the data "kayak déjà vu gitu kurasalah..." if observed based on its structure, the insertion expression includes the expression of verb phrases, but in semantic terms the insertion of "déjà vu" is included in an idiom that means someone who has experienced something as before.

Insertion of French elements in the form of reduplication is not found in this study. That is because in French, the plural form "Plurièl" is always given an article "des or les" in the form of masculine, for example in the words 'l'etudiant' and l'étudiante. In that word, the genre category can be known by looking at the article following the noun, but when the category of nominations changes into the plural "pluriel" the noun change becomes "les étudiants" (can be interpreted as students) and does not become les étudiantes (female students). So, it is difficult to interrupt the code in the form of repetition (reduplication) from French into the structure of the Indonesian language.

\section{Conclusion}

Based on the results, it is concluded that the forms of code mixing in the conversation discourse of students of the French Study Program at State University of Medan are the insertion of elements of French in the forms of nouns, numerals, verbs (infinitive and conjugation), adverb (question and time), and adjectives; the insertion of phrases (noun phrases (objects and numerals), verb phrases, and adverb phrases; the insertion of clauses (noun clauses, numeral clauses, verb clauses, and adverb clauses); and the Insertion of idiomatic forms. In addition to French, there is also the insertion of other language elements in the form of words, phrases and clauses in English. Insertion of French elements in the form of reduplication is not found in this study because in French, the plural form "Pluriel" is always given an article "des or les" in the form of masculine. In addition, there is also the insertion of elements of English into the structure of Indonesian in the forms of words, phrases, and clauses. 
Sociolinguistic discussion is included in the umbrella of science that is very interesting to be used as a study. This is because the focus of the topic in this field of science combines two fields of science, namely Sociology and Linguistics, so that there are many discussion materials and research topics that can be done using the Sociolinguistic field of science. The habit of using mixed language can also be an alternative to improve mastery of a language that is being studied like French. Therefore, the habit of training oneself to talk or communicate by involving code mixing can further enhance the ability of individuals specifically in speaking. Code mixing can also be a breakthrough for bilingualism to improve the skills in speaking foreign languages.

\section{References}

Algharabali, Alhaidari and Taqi1. 2015. "Code Switching in the French School: Examining a Multilingual Setting in Kuwait" dalam Jurnal English and Literature Studies Vol. 5 No. 4

Bell, Roger T. 1976. Sociolinguistics: Goals, Approaches, and Poblems. London: Batsford Ltd. Chaer, Abdul. 2004. Tata Bahasa Praktis Bahasa Indonesia. Jakarta: Rineka Cipta

Chaer, Abdul and Leonie Agustina. 2010. Sosiolinguistik Perkenalan Awal. Jakarta: Rineka Cipta.

Ezeizabarrena, José, Maria dan Sandrine Aeby. 2016. "Les phénomènes de code-switching dans les conversations adulte-enfant(s) en basque-espagnol : une approche syntaxique » Bases : Corpus and Langage (http://corpus.revues.org/1960)

Fishman. J. A. 1972. Sosiolinguistics: ABrief Introduction. Rowley, Massachusetts: Newbury House Publisher.

Kachru, B.B. 1982.The Bilinguals Linguistics Repertoire: International Education and Role of the Vernacular. New York: Plenary Press.

Keraf, Gorys. 2009. Diksi dan Gaya Bahasa. Jakarta: Gramedia Pustaka Utama

Sudaryanto. 2015. Metode dan Aneka Teknik Analisis Bahasa. Yogyakarta; Sanata Dharma University Press

Sumarsono. 2007. Sosiolinguistik. Yogyakarta: Sabda

Suwandi, Sarwiji. 2008. Sosiolinguistik. Surakarta: Universitas Sebelas Maret.

Weincrich, Uriel. 1968. Language in Contact. The Hauge-Paris: Mouton. 